\title{
COCAETHYLENE: A NEUROPHARMACOLOGICALLY ACTIVE METABOLITE ASSOCIATED WITH CONCURRENT COCAINE-ETHANOL INGESTION
}

\author{
P. Jatlow1,2, J.D. Elsworth2,3, C.W Bradberry2, G. Winger4, J.R. Taylor2, \\ R. Russell1 and R.H Roth 2,3
}

Departments of Laboratory of Medıcine1, Psychıatry2 and Pharmacology3, Yale University School of Medicıne, 333 Cedar St., New Haven, CT 06510 and

Department of Pharmacology4, The Unıversity of Michıgan Medical School, Ann Arbor, MI 48109

(Received in final form February 27, 1991)

\section{Summary}

\begin{abstract}
High concentrations of cocaethylene (EC), the ethyl ester of benzoylecgonine, were measured in the blood of individuals who had concurrently used cocaine and ethanol Since the powerful reinforcing effects of cocaine appear to be dependent on inhibition of dopamine reuptake in brain, we compared the effects of $E C$ on the dopamine uptake system and its behavioral effects with those of cocaine. EC was equipotent to cocaine with respect to inhibition of binding of [ $\left.{ }^{3} \mathrm{H}\right] \mathrm{GBR} 12395$ to the dopamine reuptake complex, inhibition of [ $3 \mathrm{H}]$ dopamine uptake into synaptosomes and in its ability to increase extracellular dopamine concentration in the nucleus accumbens following its systemic administration to rats. Moreover, in rats, EC and cocaine each increased locomotor activity and rearing to the same extent following i.p administration. In self-administration studies in primates, EC was approxımately equipotent to cocaine in maintaining responding. The in vivo formation of this active, transesterified ethyl homolog of cocaine may contribute to the effects and consequences of combined cocaine and ethanol abuse
\end{abstract}

In excess of $50 \%$ of cocaine abusers are reported to use ethanol $(1,2)$, most often simultaneously with cocaine (2). Anecdotal reports from cocaine abusers state that consumption of alcohol in the course of a cocaine binge prolongs the euphona and/or ameliorates the dysphoric symptoms of acute abstinence. While these effects may be a consequence of the rewarding and sedating properties of ethanol itself, recent evidence suggests that a metabolic interaction between cocaine and ethanol may provide an additional mechanism (3-7).

Smith (8) and Rafla and Epstein (9) each reported detection of traces of cocaethylene (EC), the ethyl ester of benzoylecgonine (Fig. 1A) in the urne of individuals who had concurrently used cocaine and ethanol. The assumption was that this compound resulted from the in vivo transesterification of cocaine following its use in conjunction with ethanol. The biological significance of this finding was not addressed at that tume. The demonstration of high plasma concentrations of EC, in some instances exceeding that of cocaine itself, led us to evaluate the neurochemical and behavioral properties of EC based on the possibility that this metabolite might be involved in the mechanisms and consequences of combined cocaine and ethanol abuse.

\section{Methods}

Postmortem samples from seven patients who had used both cocaine and ethanol were sent to us for investigation from the medical examıners laboratory in Dade county, where gas 
chromatographic peaks, which were presumptively identified as EC, had been observed in these samples and blood concentrations initially approximated using cocaine as a standard. We identified additional samples from Yale-New Haven Hospital Emergency Room patients for study on the basis of urine benzoylecgonine and blood alcohol analyses.

Drug Analysis: Cocane and EC concentrations were determined by reversed-phase ion painng HPLC as previously reported (10). Blood sample preparation for gas chromatography-mass spectrometry (GC/MS) was as previously described for gas chromatographic analysis of cocaine (11). EC for use as an analytical standard and for use in the neurochemical and behavioral studies, was synthesized by esterification of benzoylecgonine. Benzoylecgonine was refluxed for 6-10 hours in ethanol through which dry $\mathrm{HCl}$ gas had been passed. The ethanol was evaporated and the acid residue washed with hexane to remove any ethyl benzoate The residue was then suspended in carbonate buffer, $\mathrm{pH} \mathrm{9.6,} \mathrm{and} \mathrm{the} \mathrm{EC} \mathrm{(but} \mathrm{not} \mathrm{benzoylecgonine)} \mathrm{extracted} \mathrm{into}$ hexane. Following back extraction into acid and re-extraction into hexane, the product was 97 99\% pure by HPLC and GC/MS analysis, and free of any contaminating cocaine. In some instances, EC was subsequently crystallized from ether as the hydrochloride. A electron impact mass spectrum showed a molecular ion at m/e 317 and other major $10 n \mathrm{~s}$ at $\mathrm{m} / \mathrm{e} 196$ and $\mathrm{m} / \mathrm{e} 212$ which was consistent with published data (8). Corresponding cocane ions were at $\mathrm{m} / \mathrm{e} 182, \mathrm{~m} / \mathrm{e}$ 198 and $\mathrm{m} / \mathrm{e} 303$. High resolution proton NMR confirmed the ethyl ester substitution for the methyl ester group of cocaine.

Binding and Uptake: [3H]Dopamıne uptake and [3H]GBR bindıng were performed essentually as described previously (12). This involved the preparation of $P 2$ fraction from rat striatum or nucleus accumbens. For $[3 \mathrm{H}]$ dopamine uptake, the tissue was incubated with cocane or $\mathrm{EC}$ and desipramıne $(100 \mathrm{nM})$ in Krebs phosphate buffer ( $\mathrm{pH} \mathrm{7.4)}$ for $5 \mathrm{~min}$ at $37^{\circ} \mathrm{C}$ before adding $[3 \mathrm{H}]$ dopamine $(40 \mathrm{nM}, 37-40 \mathrm{Ci} / \mathrm{mmol}$ Dupont NEN). Two minutes later the uptake was terminated by rapid filtration through Whatman GF/C filters. The retained portion was washed and radioactivity trapped on the filter was counted. Non-specific binding was defined as the radioactivity on the filter following incubation of tissue and $\left[{ }^{3} \mathrm{H}\right]$ dopamine on 1 ce. For $\left[{ }^{3} \mathrm{H}\right] \mathrm{GBR}$ 12935 binding, tissue was incubated at $4^{\circ} \mathrm{C}$ for $15 \mathrm{hr}$ with cocaine or EC and [3H]GBR 12935 ( 2 $\mathrm{nM}, 43 \mathrm{Ci} / \mathrm{mmol}$, Dupont NEN, Boston, MA) in $50 \mathrm{mM}$ Tris buffer containing $120 \mathrm{mM} \mathrm{NaCl}$ ( $\mathrm{pH}$ 7.4). The incubation was termınated by vacuum filtration through Whatman GF/B filter paper. Each filter was rinsed and the radioactivity remanning on the filter was counted. Nonspecific binding was defined with $10 \mu \mathrm{M}$ mazindol.

Microdialysis in Rats (13-15): Concentric style microdialysis probes were constructed using Cuprophan (Enka, West Germany) hollow fibers ( $300 \mu \mathrm{m}$ 1.d., $330 \mu \mathrm{m}$ o.d.) housed in a section of 23 gauge stainless steel tubing with an exposed dialysis surface $1.5-2 \mathrm{~mm}$ long. The perfusion buffer was (in mM): $\mathrm{KCl} 24, \mathrm{NaCl} 137, \mathrm{CaCl}_{2} 1.2, \mathrm{MgCl}_{2} 1.2, \mathrm{NaH}_{2} \mathrm{PO}_{4} 0.9, \mathrm{Na}_{2} \mathrm{HPO}_{4}$ 1.4, ascorbic acid $0.3, \mathrm{pH} 7.4$ Rats were anesthetızed with chloral hydrate $(400 \mathrm{mg} / \mathrm{kg} \mathrm{i.p.})$, and placed in a stereotaxic apparatus in the flat skull position. The coordinates to which the tip of the dialysis probe were lowered vs the top of the skull at bregma were $+17 \mathrm{~A}, 1.3 \mathrm{~L}$, and $-8.3 \mathrm{~V}$. Body temperature was monitored by a rectal temperature probe and maintained with a heating pad. Following each experiment, the brain was removed and stored in formalin for later sectioning and stainıng to verify probe placement in the nucleus accumbens. Determination of dopamine concentration was accomplished using HPLC with electrochemcal detection as previously (13). The routine limit of detection was 2-3 fmols dopamine injected in a volume of 40 microliters.

Rodent Behavior: The behavioral ratıngs of locomotor actuvity and rearing were used to determine whether the drug treatments resulted in activation (16). Identical cardboard boxes were used as testing chambers for measuring rodent behavior. Quadrants were marked on the sides of the test chambers so that locomotor activity.could be measured by counting the crossings between sections. The rats were habituated to the test boxes for three hour periods two days before the test. Subjects were randomly assigned to one of three experimental groups destined to receive saline, cocaine or EC On the test day, each subject received its injection i.p. 5 min before the test. The subjects were placed in the test box for $15 \mathrm{~min}$. Behavioral ratungs were taken by one observer who was blind to the treatment Locomotor actuvity was defined as a crossing of quadrant markings on the side of the test chamber Rearing was defined as liftng both forepaws 
off the ground.

Self-Administration by Primates: The reinforcing effects of EC were evaluated in three rhesus monkeys who were trained to respond on levers and receive i.v. injections of cocaine on a fixed ratio 30 time out $45 \mathrm{sec}$ schedule of drug delivery, as described previously (17). Each selfadministration session consisted of four 25 min components of drug availability, signalled by a red stimulus light over the lever. Components were separated by 10 min. blackout periods of no drug availability. The infusion duration, and hence the dose of drug delivered, was different in each of the four session components. The standard dose range for cocaine was 0.001 to 0.03 $\mathrm{mg} / \mathrm{kg} / \mathrm{injection}$. EC was substituted for cocaine in single daily sessions over a dose range of 0.001 to $0.03 \mathrm{mg} / \mathrm{kg} / \mathrm{injection}$ in two monkeys, and over a dose range of 0.003 to 0.1 $\mathrm{mg} / \mathrm{kg} /$ injection in a third monkey. Data reported are for the observations of EC substitution and for the sessions of cocaine availability immediately preceding EC substitution.

Statistics: Data were analyzed by ANOVA followed, where approprate, by Newman-Keuls test with $p<0.05$ as the level of significance.

\section{Results}

EC concentrations in the seven human postmortem samples ranged from 73 to $1447 \mathrm{ng} / \mathrm{ml}$ (Table I) and the identity of the metabolite established by GC/MS (Figure 1). Note that in four instances, EC concentrations exceeded those of the parent compound. Ten of seventeen random emergency room blood samples in which the urine and plasma had been positive for benzoylecgonine and ethanol respectively, showed EC by HPLC. Of the seven EC negative samples, six were either negative or showed less than $5 \mathrm{ng} / \mathrm{ml}$ of cocaine. Of fourteen additional samples that were posituve by cocaine screening but were negative for ethanol, thirteen showed no EC and one sample showed a trace To exclude the possibility of in vitro artfact, we incubated $400 \mathrm{ng} / \mathrm{ml}$ of both cocaine and benzoylecgonine in blood containing ethanol $(500 \mathrm{mg} / \mathrm{dl})$ at $37^{\circ} \mathrm{C}$ for one hour and at refrigerator temperature for 24 days. To approximate the gastric environment following alcohol ingestion, we incubated $4 \mathrm{~g} / \mathrm{dl}$ alcohol with $500 \mathrm{ng} / \mathrm{ml}$ cocaine and benzoylecgonine in $0.1 \mathrm{M} \mathrm{HCl}$ at $37^{\circ} \mathrm{C}$ for two hours. EC was not formed in any of these experiments.

\section{TABLE I}

Concentrations of EC, Cocaine and Ethanol in Postmortem Blood

\begin{tabular}{cccc}
\hline Subject & $\begin{array}{l}\text { EC } \\
\text { ng/ml }\end{array}$ & $\begin{array}{l}\text { Cocaine } \\
\text { ng/ml }\end{array}$ & $\begin{array}{l}\text { Ethanol } \\
\text { mg/dl }\end{array}$ \\
\hline 1 & 1447 & 4370 & 110 \\
2 & 376 & 290 & 190 \\
3 & 164 & 135 & 50 \\
4 & 109 & 140 & 140 \\
5 & 98 & 249 & 80 \\
6 & 73 & 34 & 240 \\
7 & 142 & 91 & 20 \\
\hline
\end{tabular}

On the basis of these findings, we initiated a series of studies in order to define the pharmacological properties of EC. There was no significant difference between EC and cocaine in inhibiting the binding of the specific dopamine uptake blocker, $\left[{ }^{3} \mathrm{H}\right] \mathrm{GBR} 12935$ to rat striatal membranes ( IC $_{50} 300 \mathrm{nM}$ ), (Figure 2B). Similarly, EC was also equipotent to cocaine $\left(\right.$ IC $_{50} 250$ $\mathrm{nM})$ in inhibiting $\left[{ }^{3} \mathrm{H}\right]$ dopamine uptake into rat synaptosomes prepared from either striatum or 
nucleus accumbens (Figure 2A). Following systemic administration of EC to rats, there was a significant increase (four-fold) in extracellular dopamine concentrations in the nucleus accumbens measured by microdialysis (Figure 3 ). These increases in dopamine levels were not significantly different from those observed after the same dose of cocaine.

$\mathbf{A}$

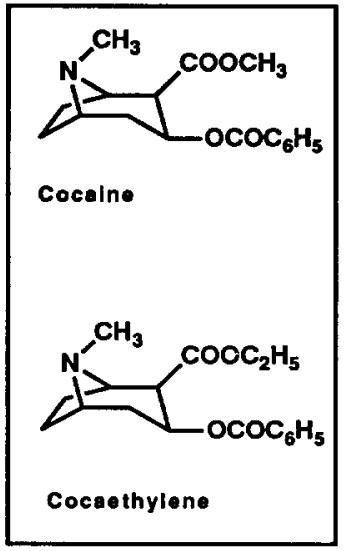

B

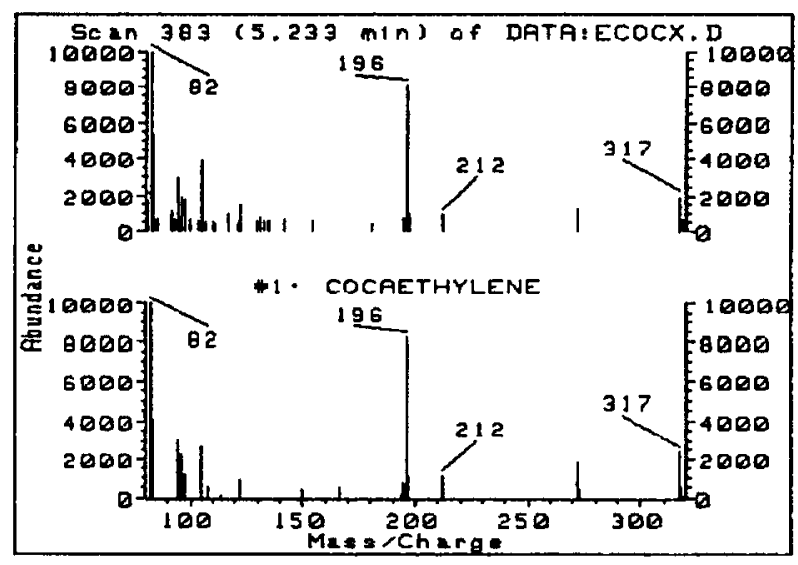

FIG. 1

A. Structures of cocaine and EC.

B. GC/MS confirmation of EC: Upper trace, from a human plasma sample (subject 1, Table I); Lower trace, authentic EC. Note molecular ion at $\mathrm{m} / \mathrm{e} 317$, and ions at $\mathrm{m} / \mathrm{e} 196$ and $\mathrm{m} / \mathrm{e} 212$. Corresponding ions for cocaine (not shown) are at $\mathrm{m} / \mathrm{e} 303, \mathrm{~m} / \mathrm{e} 182$ and $\mathrm{m} / \mathrm{e} 198$

A

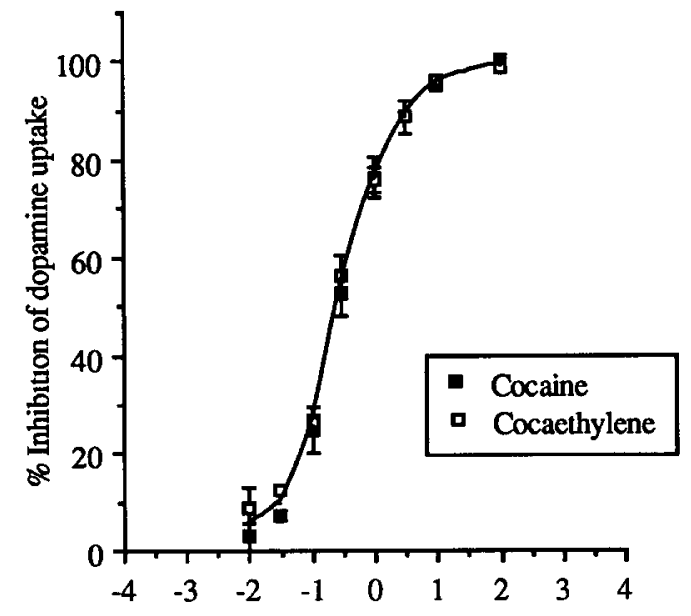

Log concentration inhıbitor $(\mu \mathrm{M})$
B

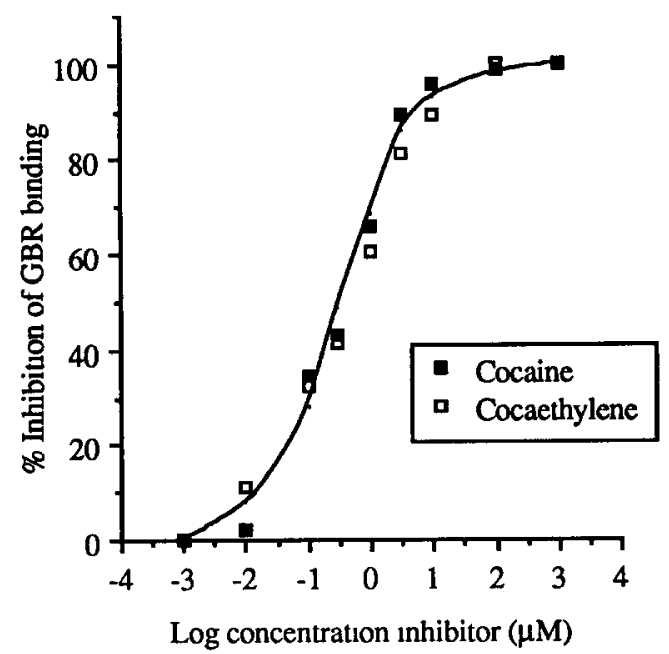

FIG. 2

A. Inhibition of [3H]dopamine uptake into rat stratal synaptosomes by cocaine and EC. Each point represents the mean $( \pm S E)$ of 3 assays carried out in duplicate.

B. Inhibition of binding of [3H]GBR 12935 to rat striatal membranes by cocaine and EC. Each point represents the mean of 2 assays carried out in triplicate. 


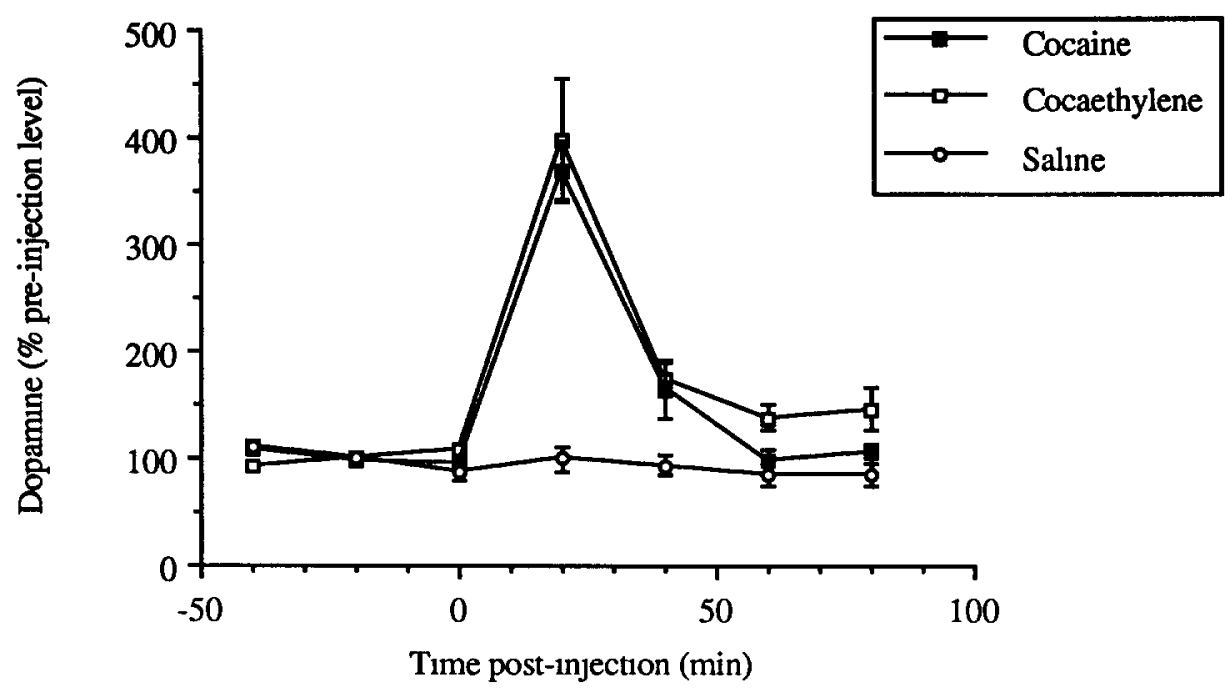

FIG. 3

Extracellular dopamine levels in rat nucleus accumbens following acute 1..v. injection of cocaine $(1 \mathrm{mg} / \mathrm{kg}, \mathrm{n}=4), E C(1 \mathrm{mg} / \mathrm{kg}, \mathrm{n}=7)$, or saline $(\mathrm{n}=7)$. Mean $( \pm$ $\mathrm{SE})$ baseline dopamine level corrected for probe recovery was $10.4 \pm 2.1$ fmol/microliter.

In rats, EC and cocaine both potently increased locomotor activity and rearing compared to salıne. There was no significant difference between EC and cocaine on locomotor activity or rearing.

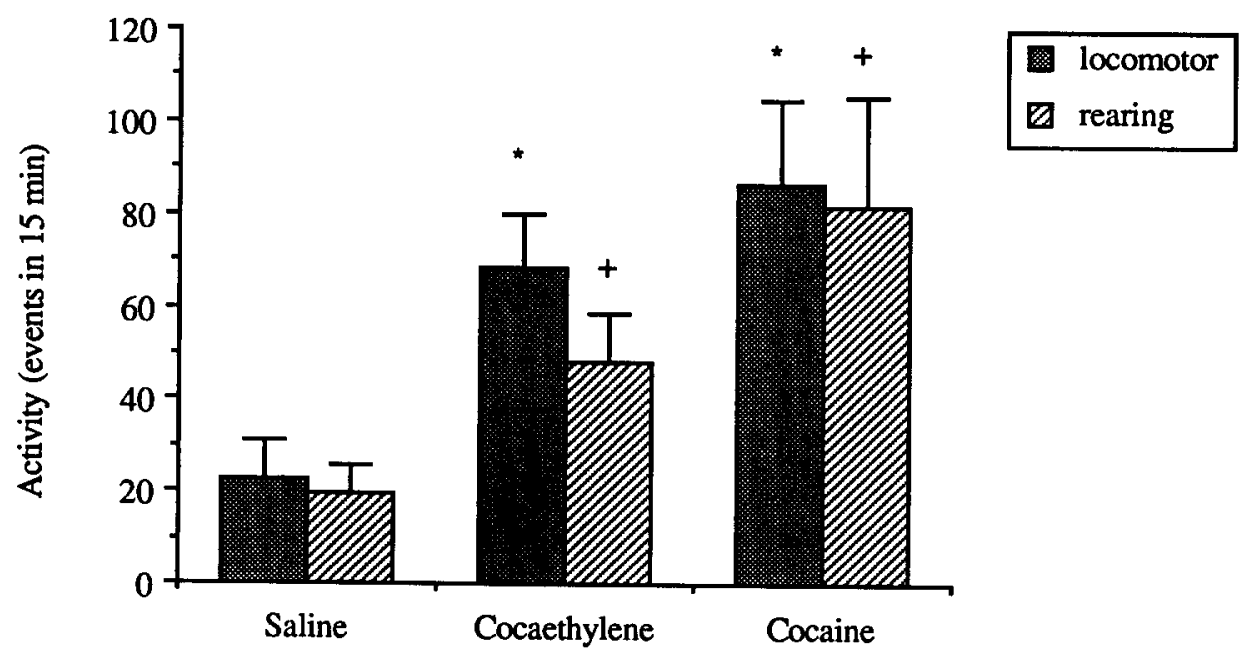

FIG. 4

Behavior of rats following i.p. injection of cocaine $(10 \mathrm{mg} / \mathrm{kg}, \mathrm{n}=5), \mathrm{EC}(10$ $\mathrm{mg} / \mathrm{kg}, \mathrm{n}=5)$ or saline $(\mathrm{n}=5)$. ${ }^{*}$ and + denote significant differences from saline treated group. 
Rates of responding in rhesus monkeys were maintained by both i.v. cocaine and by $\mathrm{EC}$ when these drugs were delivered contingently on lever press responses. Although there was some individual variation in the doses of EC that maintained maxımum rates of responding, each of the three monkeys showed rates of EC-maintained responding that were similar to or slightly higher than rates maintained by cocaine (Fig. 6). On average, the maximum rate-maintaining dose of EC was $0.01 \mathrm{mg} / \mathrm{kg} /$ injection as compared to a dose of $0.03 \mathrm{mg} / \mathrm{kg} /$ injection of cocaine. A dose of EC above that maintaining maximum rates produced response decrements, a finding that is found with virtually all drugs that maintain self-administration behavior, including cocane in this procedure (Skjoldager et al., submitted).
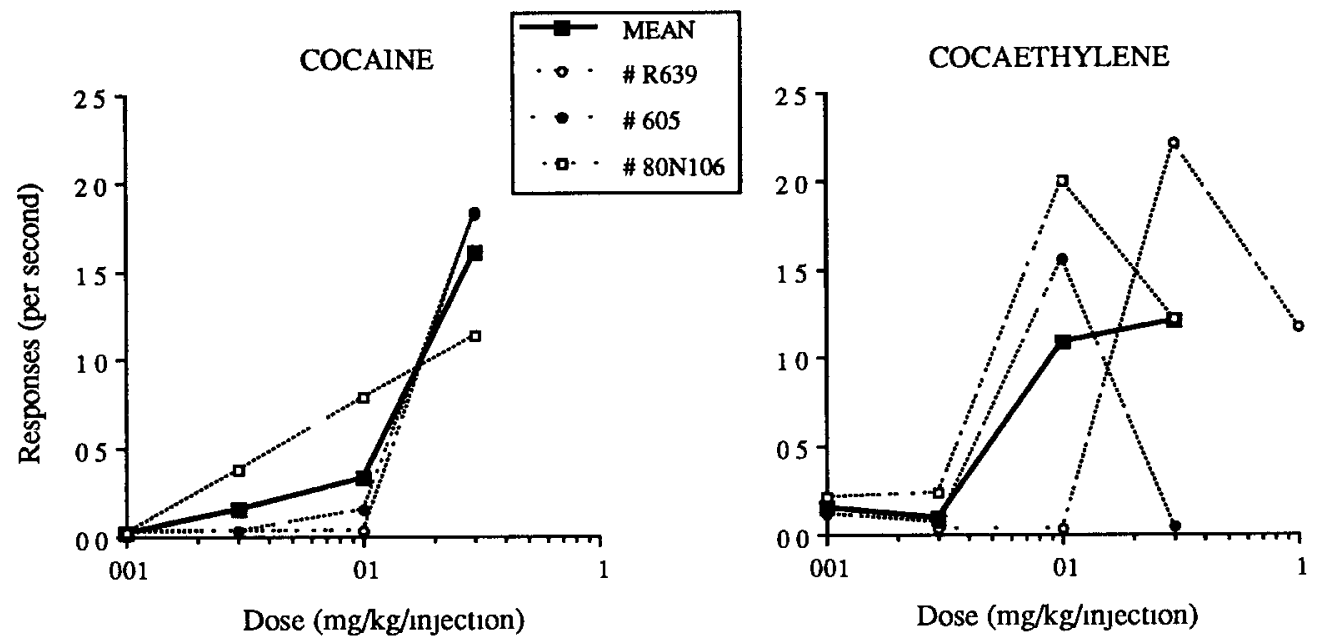

FIG 5

Mean rates of responding maintained by cocaine or $\mathrm{EC}$ in rhesus monkeys $(\mathrm{n}=3)$. Rate of responding maintained in each of the tested monkeys is also shown. Drugs delıvered contıngent on lever responses.

\section{Discussion}

The high concentrations of EC found in human blood were comparable to and in many instances well in excess of cocaine concentrations that are known to be associated whth significant pharmacological activity $(18,19)$. EC was found in most samples associated with evidence of concurrent cocaine and ethanol use and was not present when the latter was absent. Those instances where EC was not present despite the occurrence of ethanol and benzoylecgonine, cocaine was either also absent from the blood or only present in trace amounts suggesting that EC may well have been completely cleared as well. In that instance where we saw a trace of EC (less than $10 \mathrm{ng} / \mathrm{ml}$ ) despite the absence of alcohol, we suspect that the alcohol had been eliminated by the time the sample was obtained. Our incubation studies exclude the possibility of a storage artifact. EC is not a natural alkaloid of the coca leaf nor is street cocaine contaminated with EC.

Removal of the methyl ester group of cocaine to form benzoylecgonine results in an almost complete loss of affinity for the monoamine uptake carrier (20); however, it is not known what effect other substitutions at this position have. Since EC has such close structural homology to cocaine, we postulated that it might have a similar spectrum of neurochemical and behavioral propertes. We found that EC was equipotent to cocaine in its inhibition of specific ligand binding to the dopamine reuptake complex, inhibition of dopamine uptake into synaptosomes and in its ability to increase extracellular dopamine concentrations following administration to rats. The mechanism for the reinforcing properties of cocaine are thought to involve inhibition of dopamine 
reuptake with consequent elevation of synaptc dopamine levels in pathways mediating reward (2028). The similar stimulation of rat locomotor activity and rearing observed after systemic administration of EC or cocaine, suggested that this metabolite might share cocaine's psychostimulant properties.

To put our neurochemical findings into perspective, it was essential to establish whether EC was reinforcing in a primate model (29). The implications of our rodent data were confirmed by the self-administration studies in primates. EC was equipotent to cocaine and showed a similar dose response curve in maintaining lever responding in rhesus monkeys. Following cocaineethanol abuse by humans, ethanol would be present in the body in addition to cocaine and EC The effects of these drugs in combination was not directly addressed by the described experiments

Cocaine is rapidly eliminated with an approximate plasma $T_{1 / 2}$ of one hour $(30,31)$ and its acute effects disappear even more rapidly. Depending upon its rate of formation and elimination and its neurochemical properties, EC might be expected to add to cocaine's effects, prolong them and/or exhibit cross tolerance $(32,33)$ or cross sensitzzation (34) It might also better cross the blood brain barrier as a consequence of greater hydrophobicity Since repeated use of cocaine and alcohol during a binge may be associated with exposure to recurrent pulses of cocaine and $\mathrm{EC}$, sensitzation and cross sensitization might contribute to the effects of this drug combination

There have been relatively few published studies of the effects of combined cocane and ethanol administration. One study $(35)$ and two recent preliminary reports $(36,37)$ have indicated that some effects were enhanced and one indicated that subjective effects were greater following administration of cocaine and ethanol in combination than after either drug alone (37) A recent preliminary report indicated that cocaine enhanced ethanol's threshold lowerng effect on brain stımulation reward (38). This information is only suggestive and there are other possible explanations for these observations including a direct effect of ethanol on dopamine mediated reward pathways (39). In any event, further characterization of EC's neuropharmacology could enhance our understanding of the very prevalent problem of combined cocaine-ethanol abuse

\section{Acknowledgements}

Supported by DA 05119, DA 04050 and DA 04403. Postmortem samples for EC analyses and identification were provided by W.L Hearn, Ph D., Dade County Medical Examıners Office

\section{References}

1. B.F. GRANT and T.C. HARFORD, Drug and Alcohol Dependence 25 97-104 (1990).

2 R.D. WEISS, S.M. MIRIN, M.L GRIFFIN, and J.G MICHAEL, J Nerv. Ment. Dis. 176 719-725 (1988).

3. P. JATLOW, W L. HEARN, J. ELSWORTH, and R. ROTH, CPDD Annual Meetıng Abstr (1990).

4. J.D. ELSWORTH, C.W. BRADBERRY, J. TAYLOR, J R. WALKER, W L HEARN, P. JATLOW, and R.H. ROTH, Soc. Neurosc1. Abstr. 16749 (1990).

5. S. ROSE, W.L. HEARN, G.W. HIME, C V. WETLI, A.J. RUTTENBER and D.C. MASH Soc. Neurosci. Abstr. 1614 (1990).

6. D.C. MASH, D.D. FLYNN, C.V. WELTI and W L HEARN, Soc. Neurosci. Abst. 1614 (1990).

7. M.F. LIN, P.S. MCGUIRE, K A. BROWN, M.A. EVANS, C.R CHRISTIAN, E.T

HARPER and W.F. BOSRON, The Pharmacologist 31 229A (1989).

8. R.M. SMITH, J. Anal. Toxicol 8 38-42 (1984)

9. F.K. RAFLA and R.L. EPSTEIN, J Anal Toxicol. 3 59-63 (1979)

10. P. JATLOW and H. NADIM, Clin. Chem 36 1436-1439 (1990)

11. P. JATLOW and D. BAILEY, Clin. Chem 21 1918-1921 (1975).

12. P. BERGER, J.D ELSWORTH, J ARROYO, and R.H. ROTH, Eur J Pharmacol. 17791 94 (1990).

13. C.W. BRADBERRY and R.H. ROTH, Neuroscience Letters 243 61-68 (1987).

14. Y.L. HURD, J. KEHR, and U. UNGERSTEDT, J. Neurochem. 51 1314-1316 (1988). 
15. H.O. PETIT, H. PAN, L.H. PARSONS and J.D. JUSTICE, J. Neurochem. 55 798-804 (1990).

16. J.R. TAYLOR, J.D. ELSWORTH, E.J. GARCIA, S.J. GRANT, R.H. ROTH and D.E. REDMOND, JR. Psychopharmacology, 96 121-134 (1988).

17. G. WINGER, R.K. PALMER and J.H. WOODS, Drug and Alcohol Dependence 24 135-142 (1989).

18. C. VAN DYKE, P. JATLOW, J. UNGERER, P.L. BARASH, and R. BYCK, Science 191 859-861 (1976).

19. J.I. JAVAID, M.W. FISCHMAN, C.R. SCHUSTER, H. DEKIRMENJIAN, and J.M. DAVIS, Science 200 227-228 (1978).

20. M.C. RITZ, E.J. CONE and M.J. KUHAR, Life Sciences 46 635-645 (1990).

21.D.O. CALLIGARO and M.E. ELDERFRAWI Membr. B1ochem. 7 87-106 (1988).

22. N.E. GOEDERS AND J.E. SMITH, Science 221 773-775 (1983).

23. P.W. KALIVAS and P. DUFFY, Synapse 5 48-58 (1990).

24. G.F. KOOB and F.E BLOOM, Science 242 715-723 (1988)

25. M.J. KUHAR, M.C RITZ, and J. SHARKEY, Mechanisms of Cocaine Abuse and Toxicity C.D. Clouet, K. Asghar, R. Brown, Eds. NIDA Research Monograph, Rockville MD, 160184 (1988).

26. M.E.A. REITH, D.L. ALLEN, H SERSHEN, and A. LAJTHA, J. Neurochem. 43 249-55 (1984).

27. M.C. RITZ, R J LAMB, S.R. GOLDBERG, and M.J. KUHAR, Science 237 1219-1223 (1987).

28. W L. WOOLVERTON, M.S. KLEVEN, Mechanisms of Cocanne Abuse and Toxicity C.D Clouet, K Asghar, R Brown, Eds. NIDA Research Monograph, Rockville MD,160-184 (1988).

29. E.C. JOHANSON, Mechanisms of Cocaine Abuse and Toxicity C.D Clouet, K. Asghar, R. Brown, Eds. NIDA Research Monograph, Rockville MD, 34-55 (1984).

30. J AMBRE, J. Anal Toxicol. 2 241-245 (1985).

31. P. WILKINSON, C VAN DYKE, P. JATLOW, P. BARASH, and R BYCK, Clin. Pharmacol. Ther. 27 386-394 (1980)

32. M.J. CHOU, J.J. AMBRE, T.I RUO, A.J. ATKINSON, D.J. BOWSHER, and M.W. FISCHMAN, Clin. Pharmacol. Ther. 38 318-324 (1985).

33. M.W. FISCHMAN, C.R. SCHUSTER, J. JAVAID, Y. HATANO, and J. DAVIS, J. Pharmacol. Exper. Ther. 235 677-682 (1985).

34. R.M. POST. Life Sciences 26 1275-1292 (1980).

35. R.W. FOLTIN and M.W. FISCHMAN, Pharmacol. B1ochem. Behavior 31 877-883 (1989).

36. M. LYNN, S.T. HIGGINS, W.K. BICKEL, J.R. HUGHES, and M A. CAPELESS, CPDD Annual Mẹetıng Abstr. (1990).

37. M. FARRÉ, M. LLORENTE, B UGENA, X. LAMAS and J CAMI, CPDD Annual Meetıng Abstr. (1990).

38 M. MOULTEN and C. KORNETSKY, Soc. Neuro. Sci. Abstr. 16756 (1990).

39. G.D. CHIARA and A. IMPERATO, Proc. Nat. Acad. Sc1 85 5274-5278 (1988). 